\title{
INVESTIGATION OF SHEAR BEHAVIOR OF REINFORCED CONCRETE BEAMS UNDER SIMPLE AND FIXED SUPPORT CONDITIONS
}

\author{
${ }^{1}$ Mehmet KAMANLI, ${ }^{2}$ Alptug UNAL \\ 1,2Selcuk University, Department of Civil Engineering, Campus, Selcuklu, Konya, TURKEY \\ ${ }^{1}$ mkamanli@selcuk.edu.tr, ${ }^{2}$ alptugunal@gmail.com
}

(Geliş/Received:24.04.2017; Kabul/Accepted in Revised Form: 28.09.2017)

\begin{abstract}
Many experimental studies were carried out to research about reinforced concrete beams, which are an important part of the structural bearing system. In these studies, simple support conditions were generally taken into consideration. However, it is known that the support zones of beams in reinforced concrete buildings are closer to the fixed support conditions. In this study, the effect of the change of support conditions in reinforced concrete beams on the beam shear behavior was examined. For this purpose, 4 full-scale reinforced concrete beam elements were tested on a 4 point loading mechanism. Two of these specimens were tested with simple support and two with fixed support. In order to determine the behavior of the test elements, load-displacement curves were drawn, stiffness and energy consumption capacities were determined and cracks formed during the test were examined. When the test results were examined, it was found that the behavior of the fixed supported specimens was quite different from the ones of the simple supported specimens.
\end{abstract}

Key Words: Cracking patterns, Experimental study, Fixed support, Reinforced concrete beams, Simply support

\section{Betonarme Kirişlerin Basit ve Ankastre Mesnet Koşullarında Kesme Davranışının Araştırılması}

ÖZ: Yapı taşıyıcı sisteminin önemli bir parçası olan betonarme kirişler ile ilgili bir çalışma yürütülmüştür. Bu çalışmalarda genellikle basit mesnet şartları dikkate alınmıştır. Ancak, betonarme binaların mesnet bölgelerinin ankastre mesnet şartlarına daha yakın olduğu bilinmektedir. Bu çalışmada, betonarme kirişlerde mesnet şartlarının değişimin kiriş kesme dayanımına etkisi araştırılmıştır. Bu amaçla, 4 adet tam ölçekli betonarme kiriş deney elemanı 4 noktalı eğilme sisteminde test edilmiştir. Bu deney elemanlarından iki tanesi basit mesnetli, iki tanesi ise ankastre mesnetli olarak test edilmiştir. Deney elemanlarının davranışlarının belirlenmesi için yük-deplasman eğrileri çizilmiş, rijitlik ve enerji tüketim kapasiteleri belirlenmiş ve deney sırasında çatlak oluşumları gözlemlenmiştir. Deney sonuçları incelendiğinde, ankastre mesnetli deney elemanlarının davranışlarının, aynı özellikteki basit mesnetli deney elemanlarının davranışlarından oldukça farklı olduğu görülmüştür.

Anahtar Kelimeler: Çatlak özellikleri, Deneysel çalışma, Ankastre mesnet, Betonarme kiriş, Basit mesnet

\section{INTRODUCTION}

Researching about the behaviour of the beams being one of the most important parts of support system in buildings under various loads has a quite important place in the literature. Experimental studies in literature about the beams show that the beam elements were produced as simply supported and tested (Conforti et al., 2015; Kim et al., 2011; Campione and Minafo, 2012; Wang et al., 2015; Kotsovos and Pavlovic, 1997; Kamanli, 1999). This approach is a correct one for structural elements like reinforced concrete bridge beams although it is thought to be missing for the beam system in reinforced concrete buildings. As the beams in reinforced concrete buildings are fixed to the columns, the beam 
supports are neither exactly fixed support nor exactly simply support. However, the beam supports in reinforced concrete buildings are thought to be closer to the fixed support conditions.

This study aims to reveal the behavioral differences between simple supported beams and fixed supported beams. In the literature, the behaviors of fixed supported beams are not fully known. This study was carried out to determine the behaviors of the fixed supported beams.

In most of the experimental studies about the beams, specimens were produced as $1 / 2$ scale and tested (Altin and Demirel, 1997; Altin et al., 2004). Full-scale beam tests have not been preferred much by researchers due to the cost and difficulty of the test phase. However, full-scale specimens should be produced and tested in order to be able to identify real beam behaviour.

Due to the reasons mentioned above, full-scale, simply and fixed supported reinforced concrete beams were aimed to be tested in this study. Within the scope of this study, two fixed supported, two simply supported, with a/d ratio 3, full-scale reinforced concrete beams were tested on 4 point loading mechanism. In order to research about the stirrup effect on the beams under the experimental studies, two specimens with stirrup and two specimens without stirrup were tested. Load-displacement graphs about specimens tested were drawn and interpreted. Also stiffness and energy consumption capacities were determined. Interpretations were made about beam behaviour by examining fractures occurring during tests.

\section{MATERIAL AND METHOD}

Within the scope of this study, 4 full-scale beam specimens were tested on 4-point loading mechanism. Experimental studies were conducted in Selcuk University Earthquake Laboratory (Unal and Kamanli, 2016; Kamanli and Unal, 2016; Unal, 2016). Loading mechanism needs to be quite rigid as full-scale tests are intended to be made. Therefore, a different loading mechanism was created from loading mechanisms in literature (Figure 1). Since the experiments are done in full scale, the loading system must have a certain capacity. For this reason, it was considered to be supported by the rigid installation in the laboratory. In the experiments, the loading was made from the bottom, not from the top. For this reason, the beam test elements were also loaded reversely to the test mechanism. There are some examples of reverse loading in the literature (Ebead, 2015). In this study, however, a completely unique installation method was created. For simple supported experiments, two pieces of shaft were placed on the upper parts of beam support. A simple support was created by leaving a space at the bottom of the beam support zones. For fixed supported experiments, top and bottom points of the beam supports were compressed to prevent movement and rotation of the beam supports. In this way, fixed support was created. The loading mechanism designed is shown in Figure 1. Loading is done with the help of hydraulic cylinder fixed to the floor in laboratory. A load cell was put at the end of hydraulic cylinder in order to identify loads given to the beam. Load cell was fixed to a loading beam made of steel profiles. Loading points were identified by putting miller on specific points of the beam. The length of the loading point/effective depth ratio was considered as $(a / d)=3$ while identifying loading points. A mechanism made of steel profiles was prepared on support zones of specimens put on loading points.

Specimens were produced in the same size and properties. The difference between the specimens are the stirrup ratio and support conditions. No stirrup (SRCB-1 and FRCB-1) was found in the first and third specimens, while stirrup was found in other specimens (SRCB-2 and FRCB-2) at $300 \mathrm{~mm}$ intervals. Specimens were designed as full-scale. Specimens were produced $5000 \mathrm{~mm}$ in length. The distance between beam support points was $3750 \mathrm{~mm}$. Beam cross-section was designed as 250-500 $\mathrm{mm}$. 3๑16 longitudinal reinforcement was used on beams. There is no other reinforcement on the SRCB-1 and FRCB-1. In the SRCB-2 and FRCB-2, 3๑16 longitudinal reinforcement, $2 \odot 12$ montage reinforcement and ๑8/300 mm stirrup were found. Size and reinforcement properties of specimens are shown in Figure 2. The general properties of specimens were given in Table 1. 




Figure 1. Test setup

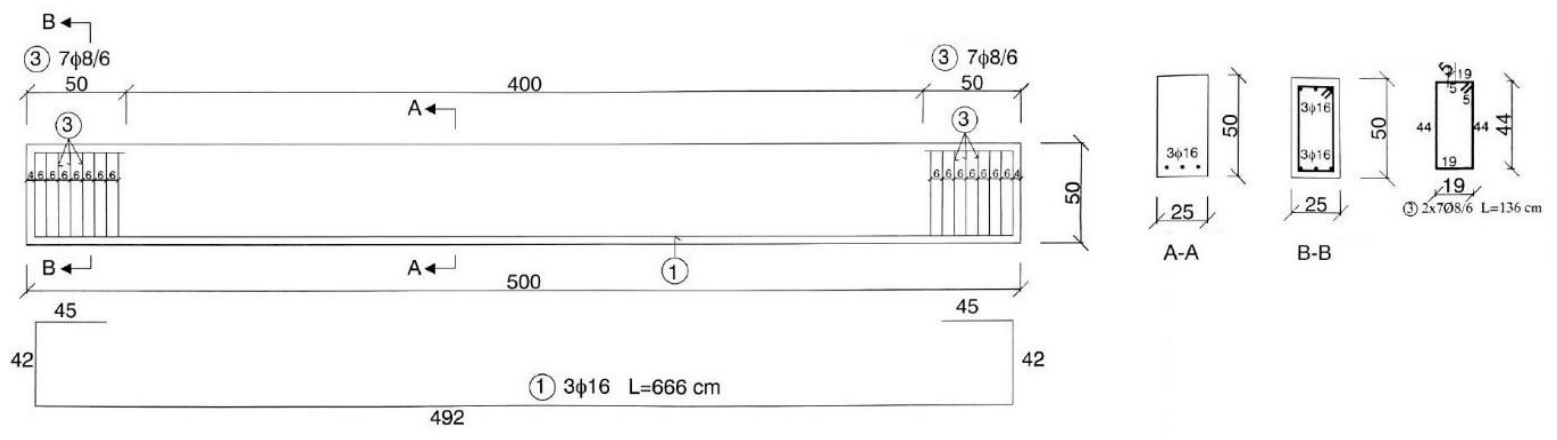

(a)



(b)

Figure 2. Properties of specimens (a) SRCB-1 and FRCB-1 (b) SRCB-2 and FRCB-2 
Table 1. General properties of specimens

\begin{tabular}{|c|ccccc|}
\hline Beam Name & a/d & $\begin{array}{c}\text { Support } \\
\text { Conditions }\end{array}$ & $\begin{array}{c}\text { Longitudinal } \\
\text { Reinforcement }\end{array}$ & $\begin{array}{c}\text { Montage } \\
\text { Reinforcement }\end{array}$ & Stirrup \\
\hline SRCB-1 & 3 & Simply & $3 \phi 16$ & - & - \\
SRCB-2 & 3 & Simply & $3 \phi 16$ & $2 \phi 12$ & $\phi 8 / 30$ \\
FRCB-1 & 3 & Fixed & $3 \phi 16$ & - & - \\
FRCB-1 & 3 & Fixed & $3 \phi 16$ & $2 \phi 12$ & $\phi 8 / 30$ \\
\hline
\end{tabular}

As specimens were produced as full-scale, material properties were considered to be appropriate for that. That's why, the concrete class was chosen as C30 and reinforcement class as S420. Properties of the materials used in specimens are shown in Table 2 and Table 3.

Specimens were produced in a prefab factory. Reinforcements were prepared according to beam properties. Reinforcements prepared were put in steel formwork in the prefab factory. Thereafter, they were molded into concrete formworks ordered from the concrete plants and specimens were created. Specimens were transferred to Selcuk University Earthquake Laboratory after standing in the factory for a week. Specimens need to stay in laboratories for 28 days to provide prescribed strength. Hence, the tests were done after this period.

\section{RESULT AND DISCUSSION}

Experimental studies within the scope of this study were made in Selcuk University Earthquake Laboratory. Tests were subjected to 4 point bending test. Tests started with load control and continued with displacement control after nominal yield value. $5 \mathrm{kN}$ load increments in load control and $5 \mathrm{~mm}$ displacement increments in displacement control were experimented in the tests.

The first crack in the SRCB-1 specimen occurred at about $20 \mathrm{kN}$ load value. Yield in the specimen occurred at $72.43 \mathrm{kN}$ load value and $15.33 \mathrm{~mm}$ displacement value. Maximum load was measured as $81.33 \mathrm{kN}$ for this specimen. Mid-point displacement at maximum load was measured as $59.79 \mathrm{~mm}$. Shear fracture occurred after maximum load and the amount of load was decreased suddenly. After the decrease in the amount of load, loading was continued for a while and then the test was ended.

The first crack in the FRCB-1 specimen occurred at about $40 \mathrm{kN}$ load value. Yield in the specimen not occurred and load was decreased suddenly because of the shear fracture. Maximum load was measured as $85.96 \mathrm{kN}$ for this specimen. Mid-point displacement at maximum load was measured as $11.18 \mathrm{~mm}$. To show the differences between fixed support and simply support load-displacement curves of SRCB-1 and FRCB-1 specimens are given in Figure 3a.

The first crack in the SRCB-2 specimen occurred at about $15 \mathrm{kN}$ load value. Yield in the test element occurred at $73.49 \mathrm{kN}$ load value and $15.22 \mathrm{~mm}$ displacement value. Maximum load was measured as $89.55 \mathrm{kN}$ for this test element. Mid-point displacement at maximum load was measured as $130.46 \mathrm{~mm}$. The test was ended after reaching the maximum load because of reaching the maximum capacity of the loading mechanism.

The first crack in the FRBC-2 specimen occurred at about $46 \mathrm{kN}$ load value. Yield in the specimen occurred at $99.86 \mathrm{kN}$ load value and $11.95 \mathrm{~mm}$ displacement value. Maximum load was measured as $150.94 \mathrm{kN}$ for this specimen. Mid-point displacement at maximum load was measured as $148.59 \mathrm{~mm}$. The test was ended after reaching the maximum load because of reaching the maximum capacity of the loading mechanism. To show the differences between fixed support and simply support loaddisplacement curves of SRCB-2 and FRCB-2 specimens are given in Figure 3b. Also load-displacement curves of all specimens are shown in Figure 4. 
Table 2. Properties of reinforced concrete

\begin{tabular}{|c|c|c|c|c|}
\hline \multicolumn{5}{|c|}{ Reinforced Concrete } \\
\hline $\begin{array}{c}\text { Specimen } \\
\text { No }\end{array}$ & $\begin{array}{c}\text { Cube Strength } \\
\text { (MPa) }\end{array}$ & $\begin{array}{c}\text { Average Cube Strength } \\
(\mathrm{MPa})\end{array}$ & $\begin{array}{c}\text { Cylinder Strength } \\
(\mathrm{MPa})\end{array}$ & $\begin{array}{c}\text { Average Cylinder Strength } \\
\text { (Mpa) }\end{array}$ \\
\hline 1 & 28.84 & \multirow{3}{*}{29.44} & 24.52 & \multirow{3}{*}{25.02} \\
\hline 2 & 28.93 & & 24.59 & \\
\hline 3 & 30.53 & & 25.95 & \\
\hline
\end{tabular}

Table 3. Properties of steel

\begin{tabular}{|c|c|c|c|c|c|c|}
\hline \multicolumn{7}{|c|}{ Steel } \\
\hline & $\begin{array}{c}\text { Specimen } \\
\text { No }\end{array}$ & $\begin{array}{c}\text { Yield } \\
\text { Strength } \\
\text { (Mpa) }\end{array}$ & $\begin{array}{c}\text { Average Yield } \\
\text { Strength } \\
\text { (Mpa) }\end{array}$ & $\begin{array}{c}\text { Tensile } \\
\text { Strength } \\
\text { (Mpa) }\end{array}$ & $\begin{array}{c}\text { Average } \\
\text { Tensile } \\
\text { Strength } \\
\text { (Mpa) }\end{array}$ & The Place of Use \\
\hline \multirow{3}{*}{$\phi 8$} & 1 & 380.77 & \multirow{3}{*}{378.72} & 468.55 & \multirow{3}{*}{454.88} & \multirow{3}{*}{ Stirrup } \\
\hline & 2 & 355.10 & & 443.07 & & \\
\hline & 3 & 400.28 & & 453.03 & & \\
\hline \multirow{3}{*}{$\phi 12$} & 1 & 368.28 & \multirow{3}{*}{386.97} & 468.06 & \multirow{3}{*}{485.37} & \multirow{3}{*}{$\begin{array}{c}\text { Montage } \\
\text { Reinforcement }\end{array}$} \\
\hline & 2 & 393.05 & & 492.39 & & \\
\hline & 3 & 399.59 & & 495.67 & & \\
\hline \multirow{3}{*}{$\phi 16$} & 1 & 410.13 & \multirow{3}{*}{409.25} & 510.85 & \multirow{3}{*}{509.72} & \multirow{3}{*}{$\begin{array}{l}\text { Longitudinal } \\
\text { Reinforcement }\end{array}$} \\
\hline & 2 & 396.00 & & 496.52 & & \\
\hline & 3 & 421.63 & & 521.80 & & \\
\hline
\end{tabular}

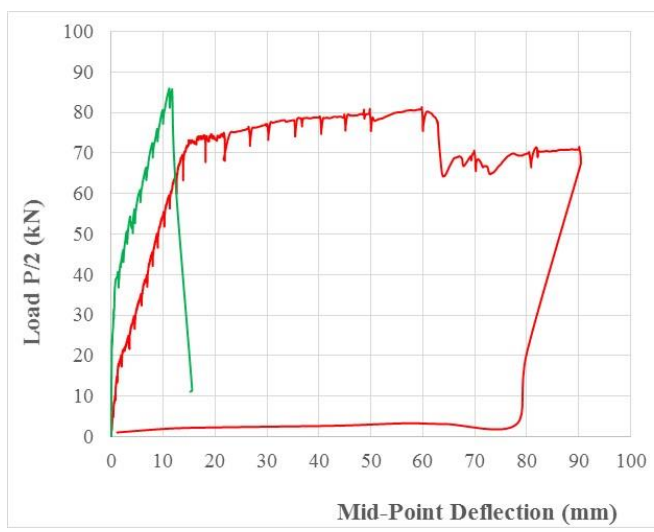

(a)

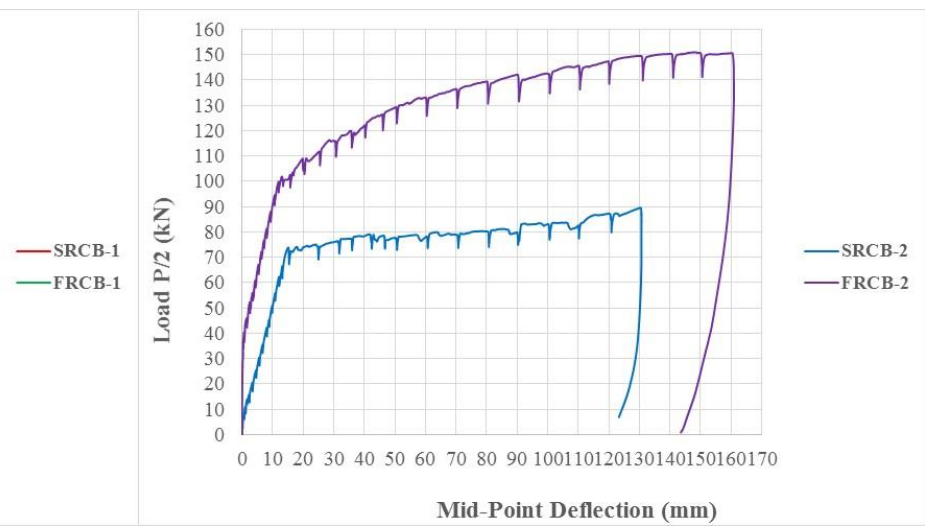

(b)

Figure 3. Load-Displacement curves (a) SRCB-1 and FRCB-1 (b) SRCB-2 and FRCB-2 


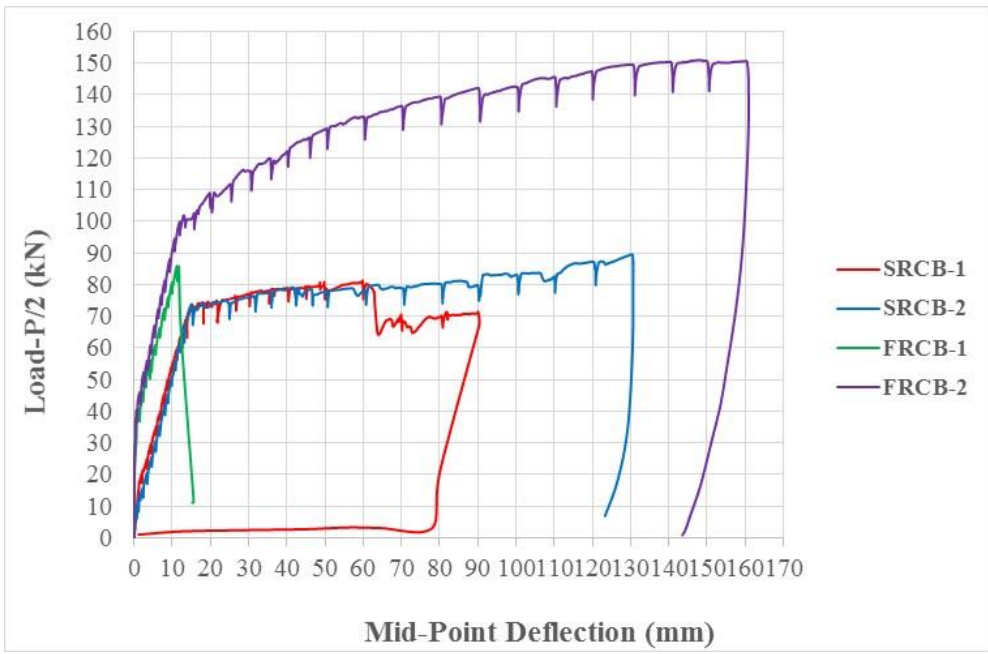

Figure 4. Load-Displacement curves of all specimens

Determination of crack distribution in the experiments gives important clues about beam behavior. After the end of the tests, cracks in the beams were examined. A shear crack occurred suddenly in SRCB1 and FRCB-1. The absence of stirrups in these specimens caused shear cracks. Cracks scattered along the surface of the beam occurred in SRCB-2 and FRCB-2. The cracks occurring in these specimens are bending cracks. The cracks in all the specimens are shown in Figure 5.

A comparative study of the test results is important for determining the effect of the stirrup in the beams on the beam behavior and the effect of different support types on beam behavior. First, the effect of the stirrups on beam behavior was examined. In the SRCB-1 and SRCB-2, the loads of the first crack and the displacements of these loads were close to each other. Likewise, their behaviors at the pour point are also similar. Since the shear crack occurred in the SRCB-1, however, the load suddenly decreased. Thus, it can be said that the stirrup used in the SRCB-2 prevented the formation of shear cracks. The SRCB-2 consumed more energy than the SRCB-1, although the initial stiffness was similar in these specimens. When the FRCB-1 and FRCB-2 were examined in terms of the stirrups, significant results were obtained. The first crack forming load and this load displacement were approximately the same in the two specimens. However, the FRCB-1 not including stirrups collapsed before reaching its yield strength. The FRCB-2 including a stirrup showed bending behavior under the influence of the stirrup and flowed at a load of about $100 \mathrm{kN}$. The maximum load reached on the FRCB-2 was approximately $76 \%$ greater than the maximum load on the FRCB-1. Similarly, when the displacements reached at the maximum load were also examined, the maximum load displacement reached on the FRCB-2 was about 13 times higher than the maximum load displacement achieved on the FRCB-1. The FRCB-2 has 3.46 times more initial stiffness than the FRCB-1. The FRCB-2 consumed considerably more energy than the FRCB-1.

Very different results were obtained when the effect of the support difference on beam behavior was examined. The support difference was effective from the beginning of the experiment. The SRCB-1 was further displaced, although the initial crack forming load on the SRCB-1 was about half of the initial crack forming load on the FRCB-1. As the beam ends were entangled in the FRCB-1 with fixed support, it showed more shear behavior than the SRCB-1. The SRCB-1 displaced 5.35 times more, although the displacement loads in these specimens were about the same. As the beam ends were entangled in the FRCB-1, its initial stiffness was 12.40 times higher than that of the SRCB-1. The energy consumption was very low in FRCB-1 because it suddenly collapsed.

Although the initial crack forming load on the FRCB-2 was 2.92 times greater than the SRCB-2, The SRCB-2 was more displaced with this load. When the cases of collapse in these specimens were examined, the FRCB-2 was 1.69 times more loaded than the SRCB-2. The FRCB-2 had about 55 times more initial stiffness than the SRCB-2. The reason for this was the fixed support of FRCB-2. The energy 
consumption of the FRCB-2 was 2.16 times greater than the energy consumption of the SRCB-2. In the light of all these evaluations, the numerical values of the test results are given in Table 4.

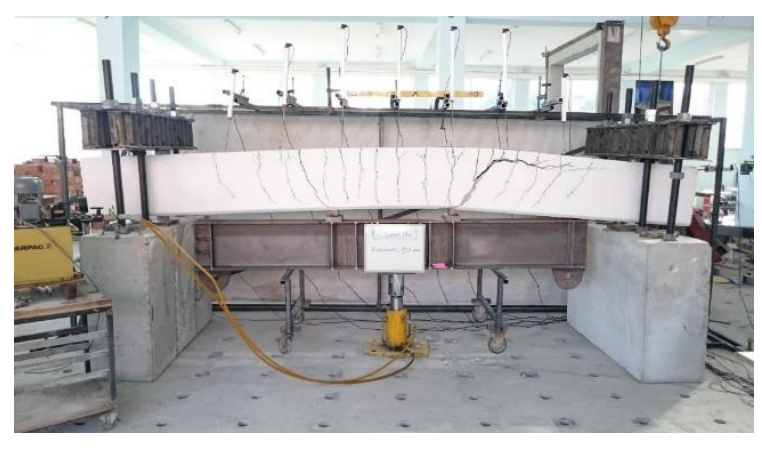

(a)

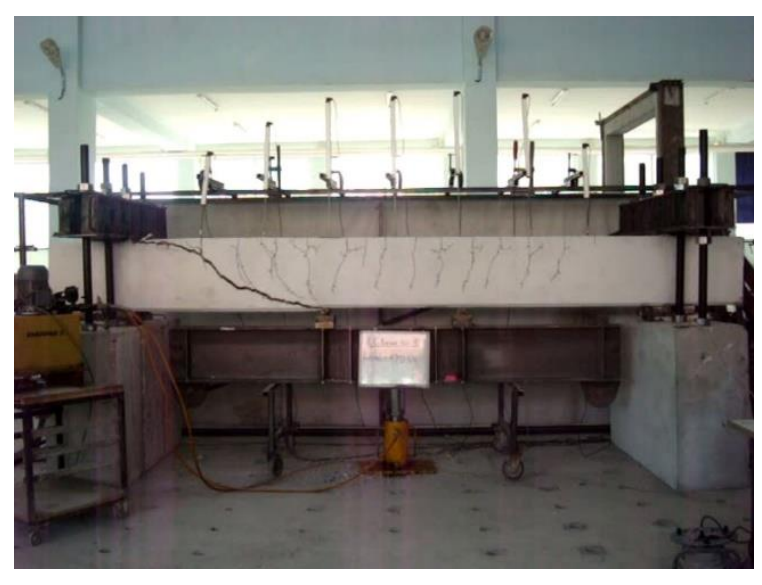

(c)

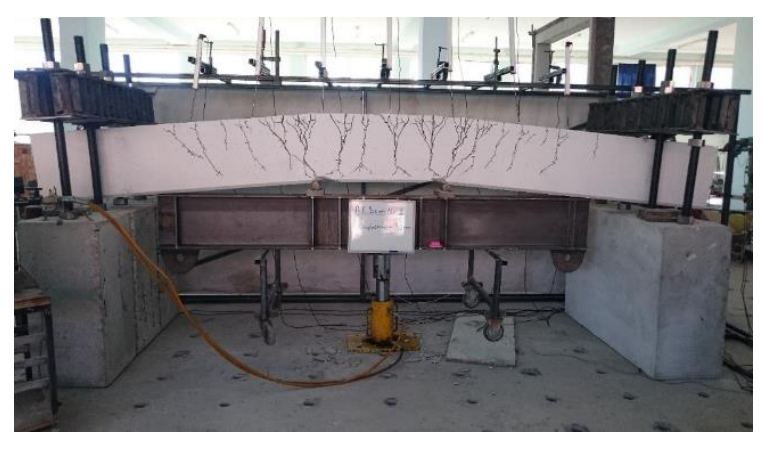

(b)

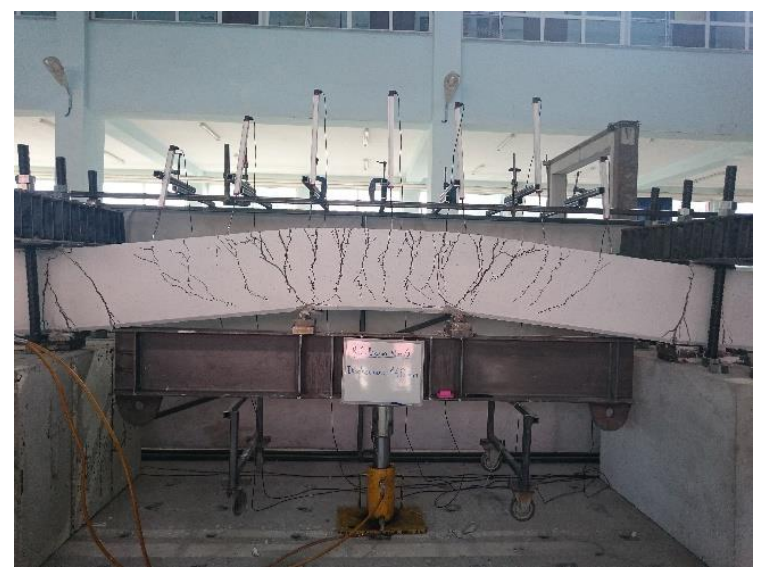

(d)

Figure 5. Fractures on the specimens (a) SRCB-1 (b) SRCB-2 (c) FRCB-1 (d) FRCB-2

Table 4. Experimental results

\begin{tabular}{|c|c|c|c|c|c|}
\hline & & SRCB-1 & SRCB-2 & FRCB-1 & FRCB-2 \\
\hline \multirow[b]{2}{*}{ First Crack } & Load (kN) & 20.11 & 15.80 & 40.72 & 46.06 \\
\hline & $\begin{array}{l}\text { Displacement } \\
(\mathrm{mm})\end{array}$ & 1.91 & 2.29 & 1.29 & 1.51 \\
\hline \multirow[b]{2}{*}{ Yield } & Load (kN) & 72.43 & 73.49 & - & 99.86 \\
\hline & $\begin{array}{l}\text { Displacement } \\
(\mathrm{mm})\end{array}$ & 15.33 & 15.22 & - & 11.95 \\
\hline \multirow[b]{2}{*}{ Fracture } & Load (kN) & 81.33 & 89.55 & 85.96 & 150.94 \\
\hline & $\begin{array}{l}\text { Displacement } \\
(\mathrm{mm})\end{array}$ & 59.79 & 130.46 & 11.18 & 148.59 \\
\hline \multicolumn{2}{|c|}{ Initial Stiffness (kN/mm) } & 18.38 & 14.37 & 227.86 & 789.29 \\
\hline \multicolumn{2}{|c|}{ Cumulative Energy (kN.m) } & 5.16 & 9.01 & 0.68 & 19.49 \\
\hline \multicolumn{2}{|c|}{ Fracture Mechanism } & Flexure+Shear & Flexure & Shear & Flexure \\
\hline
\end{tabular}




\section{CONCLUSION}

In this study, the effect of the change of the support conditions on the reinforced concrete beams and the effect of the stirrup on the beam shear behavior were examined. For this purpose, 4 beam specimens were tested: 2 with simple support and 2 with fixed support. When the test results were examined, it was seen that the stirrup used in the beams contributes to the prevention of the shear breaks in the beams. When the test results of the fixed supported specimens produced for this purpose were examined, the beam behavior was quite different from the simple supported specimens. Especially, the FRCB-2 specimen with stirrups and fixed support achieved significantly higher values of load carrying capacity, stiffness and energy consumption capacity than the other specimens. As a result, it was observed that the stirrup used in the beams increased the beam ductility, and the beam behaviors between the specimens formed according to the fixed and simple support conditions were very different. For this reason, it is thought that applying the fixed support conditions in the experimental studies related to the beams to be done in the literature will give more accurate results.

\section{ACKNOWLEDGE}

The authors would like to thank the Scientific Research Projects (SU-BAP-16401014-Konya, Turkey) of Selcuk University Coordinating Office for financial support.

\section{REFERENCES}

Altın, S., Demirel Y., 1997, “Kesmeye Karşı Güçlendirilen Betonarme Kirişlerin Davranış1- a/d=3”, IMO Technical Journal, Vol. 108, pp. 1471-1489.

Altın, S., Anıl, Ö., Gökten, Y., 2004, "Betonarme Kirişlerin Kesmeye Karşı Güçlendirilmesinde Bir Kelepçe Uygulaması", Gazi University Journal of Engineering Faculty, Vol. 19, pp. 415-422.

Campione, G., Minafò, G., 2012, "Behaviour of Concrete Deep Beams with Openings and Low Shear Span-to Depth Ratio", Engineering Structures, Vol. 41, pp. 294-306.

Conforti, A., Minelli, F., Tinini, A., Plizzari, G.A., 2015, “Influence of Polypropylene Fibre Reinforcement and Width-To-Effective Depth Ratio in Wide-Shallow Beams", Engineering Structures, Vol. 88, pp. 12-21.

Ebead, U., 2015, “Inexpensive Strengthening Technique for Partially Loaded Reinforced Concrete Beams: Experimental Study", Journal of Materials in Civil Engineering, Vol. 27(10), 04015002-1-11.

Kamanli, M., 1999, Değişken Kesitli Kirişlerin Davranışının Teorik Ve Deneysel Olarak İncelenmesi, PhD. Thesis, Graduate School of Natural Sciences, Civil Engineering, Selcuk University, Konya, Turkey.

Kamanli, M., Unal, A., 2016, “Experimental Study on Shear Behavior of Simply Supported Full Scaled Reinforced Concrete Beams", 2nd International Conference on Science, Ecology and Technology (ICONSETE-2016), Barcelona, Spain, 22- 24 August 2016.

Kim, H.S., Lee, M.S., Shin, Y.S., 2011, "Structural Behaviors of Deep RC Beams under Combined Axial and Bending Force", Procedia Engineering, Vol. 14, pp. 2212-2218.

Kotsovos, M.D., Pavlovic, M.N., 1997, "Size Effects in Beams with Small Shear Span-to-Depth Ratios", Compurers \& Structures, Vol. 44, pp. 285-295.

Unal, A., Kamanli, M., 2016, "Investigation of Stirrup Effect on Shear Behavior of Fixed Supported Reinforced Concrete Beams", 2nd International Conference on Science, Ecology and Technology (ICONSETE-2016), Barcelona, Spain, 22- 24 August 2016.

Unal, A., 2016, Sabit Dikdörtgen Kesitli Kirişlerin Farklı Mesnet Koşullarında Kesme Kapasitesinin Araştırılması, Phd Thesis, Selcuk University, Graduate School of Natural and Applied Sciences, 1-375, Konya, Turkey. 
Wang, T., Dai, J.G., Zheng, J.J., 2015, “Multi-angle Truss Model for Predicting the Shear Deformation of RC Beams with Low Span-Effective Depth Ratios", Engineering Structures, Vol. 91, pp. 85-95. 